\title{
Faktor-Faktor yang Berhubungan dengan Pantang Makanan Selama Masa Nifas di Desa Tibang Kecamatan Syiah Kuala Banda Aceh
}

\author{
Factors Relating to Abstinence from Food during the Postpartum Period in \\ Tibang Village, Syiah Kuala District, Banda Aceh
}

\author{
Raudhatun Nuzul ZA ${ }^{* 1}$, Cut Mawar Juwita ${ }^{2}$ \\ ${ }^{1}$ Program Studi D-IV Bidan Pendidik, Fakultas Ilmu Kesehatan, Universitas Ubudiyah Indonesia, Banda Aceh, Indonesia \\ ${ }^{2}$ Program Studi D-III Kebidanan, Fakultas Ilmu Kesehatan, Universitas Ubudiyah Indonesia, Banda Aceh, Indonesia \\ *Korespondensi Penulis: raudhatun@uui.ac.id
}

\begin{abstract}
Abstrak
Berdasarkan wawancara pada 10 ibu nifas didapatkan 7 dari ibu nifas masih menjalankan pantang makanan sesuai budayanya seperti tidak boleh makan daging hanya boleh makan ikan asin dan tidak mengetahui dampak dari pantang makanan tersebut dan 3 dari ibu nifas sudah mengetahui dampak dari pantangan makanan.Metode : penelitian ini merupakan penelitian survey yang bersifat analitik dengan pendekatan cross sectional. Sampel adalah seluruh ibu yang tinggal di desa Tibang Banda Aceh yang mempunyai balita $<2$ tahun yang berjumlah 60 orang, teknik pengambilan sampel dengan total sampling. Analisa data menggunakan statistik sederhana uji chi-square. Hasil: menunjukan bahwa Tidak ada hubungan sosial ekonomi dengan Pantang Makanan Selama Nifas, tidak ada hubungan pekerjaan dengan tentang pantang makanan selama nifas, ada hubungan pengalaman dengan tentang pantang makanan selama nifas, tidak ada hubungan status gizi dengan tentang pantang makanan selama nifas. Kesimpulan dan saran:Tidak ada hubungan sosial ekonomi dengan Pantang Makanan Selama Nifas, tidak ada hubungan pekerjaan dengan tentang pantang makanan selama nifas, ada hubungan pengalaman dengan tentang pantang makanan selama nifas, tidak ada hubungan status gizi dengan tentang pantang makanan selama nifas.
\end{abstract}

Kata Kunci : Pantang Makanan, Masa Nifas, Sosial Ekonomi, Status Gizi, Pengalaman

\begin{abstract}
Based on interviews with 10 postpartum mothers, 7 of the postpartum mothers still abstained according to their culture, such as not eating meat, were only allowed to eat salted fish and did not know the effects of abstinence and 3 of puerperal mothers had known the effects of dietary restrictions. Method: This study is an analytical survey research with cross-sectional approach. The sample was all mothers living in Tibang village, Banda Aceh who had <2 years old children totaling 60 people, sampling technique with total sampling. Data analysis uses simple statistics on the chi-square test. show that there is no socio-economic relationship with Abstinence during puerperium, there is no working relationship with about abstinence
\end{abstract}


from food during childbirth, there is a relationship between experience with abstinence from food during childbirth, no relationship between nutritional status and abstinence during postpartum. There is no socio-economic relationship with Abstinence during Postpartum, there is no working relationship with the abstinence of food during childbirth, there is a relationship between experience withabstinence from food during childbirth, no relationship between nutritional status and abstinence during postpartum.

Keyword : Abstinence from Food, Postpartum, Socio-Economic, Nutritional Status, Experience

\section{PENDAHULUAN}

Masalah yang sering terjadi dimasyarakat adalah adanya pantang makanan setelah melahirkan. Padahal setelah melahirkan seorang wanita memerlukan nutrisi yang cukup untuk memulihkan kembali seluruh alat genetalianya. Ibu Nifas yang melakukan pantang makanan tidak menyadari bahwa tindakannya akan berpengaruh terhadap lambatnya pemulihan kesehatan seperti semula dan juga dapat berpengaruh terhadap produksi asi (Kardinan,2008). Mengingat hal ini maka dalam masa nifas ibu harus melakukan perawatan khusus. Salah satu perawatan yang harus diperhatikan adalah pemenuhan nutrisi untuk menjaga kesehatan bayi (Sarwono, 2008).

Tarak (Pantang) terhadap makanan tidak boleh dilakukan oleh ibu post partum karena dapat memperlambat proses penyembuhan luka jahitan perineum, sedangkan dalam proses penyembuhan luka sangat membutuhkan protein, maka ibu postpartum dianjurkan untuk makan dalam pola yang benar sesuai dengan kualitas dan kuantitasnya (Iskandar ,2010). Namun pada kenyataannya, masyarakat masih banyak yang tidak memperhatikan hal tersebut. Masyarakat masih mempercayai adanya pantang makanan, mereka menerima dan menolak jenis makanan tertentu.

Di indonesia masih banyak ibu nifas yang melakukan pantang makananan pada masa nifas yaitu dari 5.123.764 ibu nifas ada 4.406.437 ibu nifas (86\%) mempunyai kebiasaan pantang makanan seperti tidak makan ikan laut, telur, sayur, dan makanan pedas, (dinkes, 2006).

Berdasarkan SDKI 2012, rata-rata angka kematian ibu (AKI) tercatat mencapai 359 per 100 ribu kelahiran hidup. Rata-rata kematian ini jauh melonjak dibanding hasil SDKI 2007 yang mencapai 228 per 100 ribu kelahiran hidup (Kemenkes, 2013)

Masih banyaknya ibu nifas yang melakukan pantang makanan menurut Sulistyoningsih (2012) di sebabkan oleh beberapa faktor diantaranya yaitu faktor predisposisi, 
faktor pendukung, dan faktor pendorong. Faktor predisposisi yang meliputi, sosial budaya, pendidikan, pengetahuan, pengalaman, pekerjaan, ekonomi, peran keluarga, dan usia, dan faktor pendukung yang terwujud dalam lingkungan fisik, tersedia atau tidak bersedianya fasilitas-fasilitas atau saranasarana kesehatan, misalnya puskesmas, obatobatan, alat-alat kontrasepsi, jamban. Serta faktor pendorong yang terwujud dalam sikap dan perilaku petugas kesehatan atau petugas lainnya yang merupakan kelompok retevensi dari perilaku masyarakat (paath, 2005). Sosial budaya atau kebiasaan merupakan salah satu faktor yang sangat mempengaruhi perilaku ibu nifas dalam melakukan pantangan makanan pada masa nifas.

Seiring dengan perkembangan teknologi dan informasi membawa perubahan terhadap pengetahuan dan sikap ibu terhadap gizi yang mengalami perubahan positif, namun perubahan tersebut belum maksimal sebagaimana yang diharapkan. Dibeberapa pelayanan kesehatan masih ditemukan ibu-ibu yang kurang memiliki pengetahuan tentang kebutuhan gizi pada masa nifas. Ibu-ibu kadang menunjukkan perilaku negatif seperti pantangan minum susu dan makan ikan, sehingga kepercayaan ibu nifas pantang mengonsumsi makanan tertentu menyebabkan kondisi ibu kehilangan zat gizi yang berkualitas (Eslimah, 2009).

Salah satu faktor yang secara langsung dapat mempengaruhi kondisi kesehatan ibu yang baru melahirkan adalah makanan yang diberikan. Dalam setiap masyarakat ada aturanaturan yang menentukan kuantitas, kualitas dan jenis-jenis makanan yang seharusnya dan tidak seharusnya dikonsumsi oleh anggota-anggota suatu rumah tangga, sesuai dengan kedudukan, usia, jenis kelamin dan situasi-situasi tertentu. Misalnya, ibu yang sedang hamil tidak diperbolehkan atau dianjurkan untuk mengonsumsi makanan tertentu; ayah yang bekerja sebagai pencari nafkah berhak mendapat jumlah makanan yang lebih banyak dan bagian yang lebih baik daripada anggota keluarga yang lain; atau anak laki-laki diberi makan lebih dulu daripada anak perempuan (Haryono). Nifas masalah diet perlu mendapatkan perhatian yang serius, karena dengan nutrisi yang baik dapat mempercepat penyembuhan ibu d, 2006).

Pada masa an sangat mempengaruhi susunan air susu. Diet yang diberikan harus bermutu, bergizi tinggi, cukup kalori, tinggi protein dan banyak mengandung cairan (Saleha, 2009).Banyak praktek-praktek budaya yang berpengaruh secara negatif terhadap perilaku kesehatan masyarakat, sehingga lebih besar untuk mengalami infeksi. Pada beberapa budaya, pantang makan pada ibu hamil dan ibu nifas dapat berpengaruh pada asupan gizi (Suprabowo, 2006 ). 
Dampak lain yang ditimbulkan dari budaya yang melakukan pantangan makan pada ibu nifas adalah terjadinya anemia. Penyebab anemia pada masa nifas yang pertama terjadi karena infeksi, apalagi bagi ibu yang ketika persalinan mengalami perdarahan, proses melahirkan yang sangat lama atau bisa jadi ibu sudah mengalami anemia pada masa kehamilan dan kemudian hal ini diperberat lagi dengan melakukan pantangan makan pada masa nifas maka ibu akan mengalami anemia berat (Harnany, 2006).

Berdasarkan studi pendahuluan awal di desa Tibang kecamatan Syiah Kuala Banda Aceh pada tahun 2015 jumlah ibu yaitu 297 orang dan pada tahun 2016 jumlah ibu yang memiliki balita $<2$ tahun yaitu 60 orang, berdasarkan wawancara pada 10 ibu nifas didapatkan 7 dari ibu nifas masih menjalankan pantang makanan sesuai budayanya seperti tidak boleh makan daging hanya boleh makan ikan asin dan tidak mengetahui dampak dari pantang makanan tersebut dan 3 dari ibu nifas sudah mengetahui dampak dari pantangan makanan.

Berdasarkan hal tersebut maka penulis tertarik untuk melakukan penelitian dengan judul "Faktor-Faktor Yang Berhubungan Dengan Pantang Makanan Selama Masa Nifas Di Desa Tibang Banda Aceh”.

\section{METODE PENELITIAN}

Penelitian ini bersifat survei analitik dengan rancangan penelitan cross sectional. Sampel dalam penelitian ini seluruh ibu yang memiliki balita $<2$ tahun yang berjumlah 60 orang. Dengan tekhnik pengampilan sampel total populasi. Data pengumpulan menngunakan data primer dan sekunder.

\section{HASIL DAN PEMBAHASAN}

Tabel 1. Hubungan Status Ekonomi dengan Pantang Makanan pada Ibu Nifas di Desa Tibang Kecamatan Syiah Kuala Tahun 2016

\begin{tabular}{|c|c|c|c|c|c|c|c|}
\hline \multirow{3}{*}{ No. } & \multirow{3}{*}{$\begin{array}{c}\text { Status } \\
\text { Ekonomi }\end{array}$} & \multicolumn{4}{|c|}{ Pantang Makanan } & \multirow{3}{*}{ Total } & \multirow{3}{*}{$\begin{array}{c}\text { Uji } \\
\text { Statistik } \\
\text { Pvalue }\end{array}$} \\
\hline & & \multicolumn{2}{|c|}{ Tidak Melakukan } & \multicolumn{2}{|c|}{ Melakukan } & & \\
\hline & & $\mathbf{F}$ & $\%$ & $\mathbf{F}$ & $\%$ & & \\
\hline 1 & Tinggi & 36 & 81,8 & 8 & 18,2 & $44(100 \%)$ & 0716 \\
\hline 2 & Rendah & 12 & 75,0 & 4 & 25,0 & $16(100 \%)$ & $0, / 10$ \\
\hline
\end{tabular}

Sumber : data diolah tahun 2016 
Menunjukkan dari 44 ibu yang status ekonominya tinggi yang tidak melakukan pantang makanan selama nifas yaitu 36 responden $(81,8 \%)$ dan dari 16 ibu yang status ekonominya rendah yang melakukan tidak pantangan makanan selama nifas yaitu 12 responden (75,0\%). Setelah dilakukan uji statistik dengan Chi Square test diperoleh nilai $\mathrm{p}=$ 0.716 ( $p>0.05)$, dengan demikian hipotesa menyatakan tidak ada hubungan sosial ekonomi dengan Pantang Makanan Selama Nifas di Desa Tibang Banda Aceh Tahun 2016 terbukti (diterima).

Tabel 2. Hubungan Pekerjaan dengan Pantang Makanan pada Ibu Nifas di Desa Tibang Kecamatan Syiah Kuala Tahun 2016

\begin{tabular}{|c|c|c|c|c|c|c|c|}
\hline \multirow{3}{*}{ No } & \multirow{3}{*}{ Pekerjaan } & \multicolumn{4}{|c|}{ Pantang Makanan } & \multirow{3}{*}{ Total } & $\begin{array}{c}\text { Uji } \\
\text { Statistik }\end{array}$ \\
\hline & & \multicolumn{2}{|c|}{ Tidak Melakukan } & \multicolumn{2}{|c|}{ Melakukan } & & \multirow{2}{*}{ Pvalue } \\
\hline & & $\mathbf{F}$ & $\%$ & $\mathbf{F}$ & $\%$ & & \\
\hline \multirow{2}{*}{$\begin{array}{l}1 \\
2\end{array}$} & Bekerja & 29 & 87,9 & 4 & 12,1 & $33(100 \%)$ & \multirow[b]{2}{*}{0,173} \\
\hline & $\begin{array}{c}\text { Tidak } \\
\text { Bekerja }\end{array}$ & 19 & 70,4 & 8 & 29,6 & $27(100 \%)$ & \\
\hline
\end{tabular}

Sumber : data diolah tahun 2016

Menunjukkan bahwa dari 33 ibu yang bekerja yang tidak melakukan pantang makanan yaitu 29 ibu (87,9\%) dan dari 27 ibu yang tidak bekerja yang melakukan pantang makanan yaitu 8 ibu (29,6\%). Setelah dilakukan uji statistik dengan Chi Square test diperoleh nilai p = 0.173 ( $\mathrm{p}>0.05$ ), dengan demikian hipotesa menyatakan tidak ada hubungan pekerjaan dengan Pantang Makanan Selama Nifas di Desa Tibang Banda Aceh Tahun 2016 terbukti (diterima).

Tabel 3. Hubungan Status Gizi dengan Pantang makanan pada Ibu Nifas di Desa TibangKecamatan Syiah Kuala Tahun 2016

\begin{tabular}{|c|c|c|c|c|c|c|c|}
\hline \multirow{3}{*}{ No. } & \multirow{3}{*}{$\begin{array}{c}\text { Status } \\
\text { Gizi }\end{array}$} & \multicolumn{4}{|c|}{ Pantang Makanan } & \multirow{3}{*}{ Total } & \multirow{3}{*}{$\begin{array}{c}\text { Uji } \\
\text { Statistik } \\
\text { Pvalue }\end{array}$} \\
\hline & & \multicolumn{2}{|c|}{ Tidak Melakukan } & \multicolumn{2}{|c|}{ Melakukan } & & \\
\hline & & $\mathbf{F}$ & $\%$ & $\mathbf{F}$ & $\%$ & & \\
\hline 1 & Normal & 42 & 82,4 & 9 & 17,6 & $51(100 \%)$ & \\
\hline 2 & KEK & 6 & 66,7 & 3 & 33,3 & $9(100 \%)$ & 0,365 \\
\hline
\end{tabular}

Sumber : data diolah tahun 2016

Menunjukkan bahwa dari 51 ibu yang status gizinya normal yang tidak melakukan pantang makanan yaitu 42 ibu $(82,4 \%)$ dan dari 9 ibu yang status gizinya KEK yang 
melakukan pantang makanan yaitu 3 ibu (33,3\%). Setelah dilakukan uji statistik dengan Chi Square Test diperoleh nilai $\mathrm{P}=0.365$ ( $\mathrm{p}>0.05)$, dengan demikian hipotesa yang menyatakan tidak ada hubungan status gizi dengan Pantang Makanan Selama Nifas di Desa Tibang Banda Aceh Tahun 2016 terbukti (diterima).

Tabel 4. Hubungan Pengalaman dengan Pantang makanan pada Ibu Nifas di Desa Tibang Kecamatan Syiah Kuala Tahun 2016

\begin{tabular}{|c|c|c|c|c|c|c|c|}
\hline \multirow{3}{*}{ No. } & \multirow{3}{*}{ pengalaman } & \multicolumn{4}{|c|}{ Pantang Makanan } & \multirow{3}{*}{ Total } & \multirow{3}{*}{$\begin{array}{c}\text { Uji } \\
\text { Statistik } \\
\text { Pvalue }\end{array}$} \\
\hline & & \multicolumn{2}{|c|}{ Tidak Melakukan } & \multicolumn{2}{|c|}{ Melakukan } & & \\
\hline & & $\mathbf{F}$ & $\%$ & $\mathbf{F}$ & $\%$ & & \\
\hline 1 & Baik & 45 & 93,8 & 3 & 6,2 & $48(100 \%)$ & \multirow{2}{*}{0,000} \\
\hline 2 & Kurang & 3 & 25,0 & 9 & 75,0 & $12(100 \%)$ & \\
\hline
\end{tabular}

Sumber : data diolah tahun 2016

Menunjukkan bahwa dari 48 ibu yang pengalamannya baik yang tidak melakukan pantang makanan yaitu 45 ibu $(93,8 \%)$ dan dari 12 ibu yang pengalamannya kurang yang melakukan pantang makanan yaitu 9 ibu (75,0\%).Setelah dilakukan uji statistik dengan $C h i$ Square Test diperoleh nilai $\mathrm{P}=0.000(\mathrm{p}<0.05)$, dengan demikian hipotesa yang menyatakan ada hubungan Pengalaman dengan Pantang Makanan Selama Nifas di Desa Tibang Banda Aceh Tahun 2016 terbukti (diterima).

\section{Pembahasan}

1. Hubungan Sosial Ekonomi dengan Pantang Makanan

Berdasarkan tabel diatas menunjukkan dari 44 ibu yang status ekonominya tinggi yang tidak melakukan pantang makanan selama nifas yaitu 36 responden $(81,8 \%)$ dan dari 16 ibu yang status ekonominya rendah yang melakukan tidak pantangan makanan selama nifas yaitu 12 responden (75,0\%). Setelah dilakukan uji statistik dengan Chi Square test diperoleh nilai $\mathrm{p}=0.716(\mathrm{p}>0.05)$, dengan demikian hasil yang saya dapatkan menyatakan tidak ada hubungan sosial ekonomi dengan Pantang Makanan Selama Nifas di Desa Tibang Banda Aceh Tahun 2016.

Hasil penelitian ini sesuai dengan hasil penelitian yang dilakukan oleh Eka Setya pada tahun 2010 dengan hasil penelitian yaitu tidak ada hubungan sosial ekonomi dengan pantang makanan pada masa nifas dengan hasil uji statistik didapatkan Pvalue $=0,367$ (> 
0,05) yang artinya tidak ada hubungan sosial ekonomi dengan pantang makanan pada masa nifas.

Hasil penelitian ini tidak sesuai dengan hasil penelitian yang dilakukan oleh Mimi pada tahun 2011 dengan hasil penelitian yaitu ada hubungan antara status ekonomi dengan pantang makanan pada ibu nifas dengan nilai Pvalue $=0,001(<0,05)$ maka hipotesa ada hubungan status ekonomi dengan pantang makanan pada ibu nifas diterima.

Paath (2005) mengatakan status ekonomi merupakan simbol status sosial di masyarakat. Pendapatan yang tinggi menunjukan kemampuan masyarakat dalam memenuhi kebutuhan nutrisi yang memenuhi faedah zat gizi untuk ibu hamil. Sedangkan kondisi ekonomi keluarga yang rendah mendorong ibu nifas untuk melakukan tindakan yang tidak sesuai dengan kebutuhan kesehatan.

Masih banyaknya ibu nifas yang melakukan pantang makanan menurut Sulistyoningsih (2012) di sebabkan oleh beberapa faktor diantaranya yaitu faktor predisposisi, faktor pendukung, dan faktor pendorong. Faktor predisposisi yang meliputi, sosial budaya, pendidikan, pengetahuan, pengalaman, pekerjaan, ekonomi, peran keluarga, dan usia, dan faktor pendukung yang terwujud dalam lingkungan fisik, tersedia atau tidak bersedianya fasilitas-fasilitas atau saranasarana kesehatan, misalnya puskesmas, obatobatan, alat-alat kontrasepsi, jamban.

Peneliti berasumsi bahwa ekonomi tidak berhubungan dengan status ekonomi karena tidak semua ibu yang berstatus ekonomi rendah melakukan pantang makanan karena ibu yang berstatus ekonomi tinggi juga ada yang melakukan pantang makanan selama masa nifas ibu. Peneliti juga berasumsi bahwa status ekonomi tidak berhubungan dengan pantang makanan selama masa nifas dikarenakan keterbatasan penelitian yaitu karena sebagian besar responden penelitian adalah ibu yang berstatus ekonomi tinggi. Dan bahwa status ekonomi tidak berhubungan dengan pantang makanan pada masa nifas karena ibu yang melakukan pantangan makanan dimasa nifas saat ini tidak terbatas pada ibu yang ekonomi rendah pada ibu yang ekonomi tinggi juga ada melakukan pantang makanan pada masa nifas.

2. Hubungan Pekerjaan dengan Pantang Makanan

Berdasarkan tabel diatas makanan yaitu 29 ibu (87,9\%) dan dari 27 ibu yang tidak bekerja yang melakukan pantang makanan yaitu 8 ibu $(29,6 \%)$. Setelah dilakukan uji 
statistik dengan Chi Square test diperoleh nilai $\mathrm{p}=0.173$ ( $\mathrm{p}>0.05)$, dengan demikian hipotesa menyatakan tidak ada hubungan pekerjaan dengan Pantang Makanan Selama Nifas di Desa Tibang Banda Aceh Tahun 2016 terbukti (diterima). Hasil penelitian ini tidak sesuai dengan hasil penelitian yang dilakukan oleh Dewi tahun 2009 dengan hasil penelitian yaitu ada hubungan antara pekerjaan dengan pantang makanan dengan nilai $\mathrm{P}$ value $=0,013(<0,05)$.

Paath (2005) mengatakan pekerjaan merupakan suatu usaha dalam memperoleh imbalan yaitu uang. Suami yang bekerja akan mendukung ibu dalam memenuhi kebutuhan masa nifas yang mengandung banyak zat gizi, sedangkan ibu yang bekerja menyebabkan ibu mempunyai kesempatan untuk bertukar informasi dengan rekan kerja tentang pantang makanan.

Peneliti berasumsi bahwa perkerjaan tidak berhubungan dengan pantang makanan karena ibu yang bekerja saat ini juga masih ada yang melakukan pantang sama seperti ibu yang tidak bekerja sehingga pekerjaan tidak berhubungan dengan pantang makanan pada ibu nifas. Peneliti juga menemukan bahwa ibu bekerja masih melakukan pantang makanan dapat dikarenakan budaya dan dukungan keluarga.

\section{Hubungan Status Gizi dengan Pantang Makanan}

Berdasarkan tabel diatas menunjukkan bahwa dari 51 ibu yang status gizinya normal yang tidak melakukan pantang makanan yaitu 42 ibu $(82,4 \%)$ dan dari 9 ibu yang status gizinya KEK yang melakukan pantang makanan yaitu 3 ibu (33,3\%). Setelah dilakukan uji statistik dengan Chi Square Test diperoleh nilai $\mathrm{P}=0.365$ ( $\mathrm{p}>0.05)$, dengan demikian hipotesa yang menyatakan tidak ada hubungan status gizi dengan Pantang Makanan Selama Nifas di Desa Tibang Banda Aceh Tahun 2016 terbukti (diterima).

Menurut Kardinan (2008) mengatakan masalah yang sering terjadi dimasyarakat adalah adanya pantang makanan setelah melahirkan. Padahal setelah melahirkan seorang wanita memerlukan nutrisi yang cukup untuk memulihkan kembali seluruh alat genetalianya. Ibu Nifas yang melakukan pantang makanan tidak menyadari bahwa tindakannya akan berpengaruh terhadap lambatnya pemulihan kesehatan seperti semula dan juga dapat berpengaruh terhadap produksi asi.

Sesuai dengan penelitian hasil penelitian ini sejalan dengan penelitian yang dilakukan oleh Rosnita tahun 2010 dengan hasil penelitian yang menunjukkan bahwa 
tidak ada hubungan antara status gizi dengan pantang makanan pada ibu nifas dengan nilai Pvalue $=0,327(>0,05)$ dapat disimpulkan bahwa hipotesa tidak ada hubungan status gizi dengan pantang makanan pada masa nifas diterima.

Penelitian ini sesuai dengan hasil penelitian yang dilakukan oleh Yulianan tahun 2011 dengan hasil penelitian yang menunjukkan bahwa tidak ada hubungan antara status gizi dengan pantang makanan pada ibu nifas dengan nilai Pvalue $=0,063(>0,05)$ dapat disimpulkan bahwa hipotesa tidak ada hubungan status gizi dengan pantang makanan pada masa nifas diterima.

Peneliti berasumsi bahwa status gizi tidak berhubungan dengan pantang makanan karena masih banyak ibu sekarang sudah berstatus gizi normal atau tidak kekurangan gizi melakukan pantangan makanan pada masa nifas dan ibu yang melakukan pantang makanan juga tidak hanya ibu yang berstatus gizi KEK tetapi ibu yang status gizi normal juga melakukan pantang makanan

\section{Hubungan Pengalaman dengan Pantang Makanan}

Berdasarkan tabel diatas menunjukkan bahwa dari 48 ibu yang pengalamannya baik yang tidak melakukan pantang makanan yaitu $45 \mathrm{ibu}(93,8 \%)$ dan dari $12 \mathrm{ibu}$ yang pengalamannya kurang yang melakukan pantang makanan yaitu 9 ibu $(75,0 \%)$. Setelah dilakukan uji statistik dengan Chi Square Test diperoleh nilai $\mathrm{P}=0.000(\mathrm{p}<0.05)$, dengan demikian hipotesa yang menyatakan ada hubungan Pengalaman dengan Pantang Makanan Selama Nifas di Desa Tibang Banda Aceh Tahun 2016 terbukti (diterima).

Hasil penelitian ini sesuai dengan hasil penelitian yang dilakukan oleh Fazilah tahun 2011 dengan hasil penelitian yaitu ada hubungan antara pengalaman dengan pantang makanan pada ibu nifas dengan nilai Pvalue $=0,000(<0,05)$, maka hipotesa yang menyatakan ada hubungan pengalaman dengan pantang makanan pada masa nifas diterima.

Paath (2005) yang mengatakan pengalaman merupakan sumber pengetahuan dan tindakan sesorang dalam melakukan sesuatu hal. Adanya pengalaman melahirkan dan menjalani masa nifas maka ibu akan mempunyai perilaku yang mengacu pada pengalaman yang telah dialami sebelumnya. Misalnya ibu nifas yang dahulunya mengalami masalah baik pada dirinya dan bayinya karena pantang makanan maka ibu nifas tidak akan melakukan pantang makanan kembali pada masa nifas berikutnya. 
Peneliti berasumsi bahwa pengalaman sangat berhubungan terhadap pantang makanan karena ibu yang sudah pernah mempunyai pengalaman melakukan pantang makanan tetapi tidak mengalami masalah akan melakukan pantang makanan lagi kedepan karena menurut ibu itu merupakan tradisi di daerah ibu tersebut dan didukung oleh keluarga seperti ibu kandung atau ibu mertua dan ibu akan merasa diasingkan dikeluarga apabila tidak melakukan pantangan makanan karena pantang makanan merupakan tradisi atau budaya keluarga ibu. Pengalaman sangat berhubungan karena seorang ibu yang mempunyai pengalaman pada saat menjalani masa nifas sebelumnya apabila mengalami masalah pada ibu atau bayi yang disebabkan oleh pantang makanan maka ibu tidak akan melakukan pantangan makanan pada masa nifas kedepannya.

\section{KESIMPULAN}

1. Tidak ada hubungan sosial ekonomi dengan Pantang Makanan Selama Nifas di Desa Tibang Banda Aceh Tahun 2016 dengan nilai Pvalue= 0,716 (>0,05).

2. Tidak ada hubungan pekerjaan dengan tentang pantang makanan selama nifas di Desa Tibang Banda Aceh Tahun 2016 dengan nilai Pvalue= 0,713 (>0,05).

3. Adahubungan pengalaman dengan tentang pantang makanan selama nifas di Desa Tibang Banda Aceh Tahun 2016 dengan Pvalue=0,000 $(<0,05)$.

4. Tidak ada hubungan status gizi dengan tentang pantang makanan selama nifas di Desa Tibang Banda Aceh Tahun 2016 dengan Pvalue= 0,365 (>0,05).

\section{SARAN}

Diharapkan penelitian ini dapat memberi informasi kepada ibu dampak negatif dari pantang makanan selama nifas sehingga ibu kedepan tidak melakukan pantang makanan yang merugikan ibu

\section{DAFTAR PUSTAKA}

Bahiyatun. 2009. Buku Ajar Asuhan Kebidanan Nifas Normal. Jakarta: EGC

Marmi S. 2012. Asuhan Kebidanan Nifas. Yogyakarta: Pustaka Pelajar

Notoadmodjo. 2010. Metodelogi Penelitian Kesehatan. Jakarta: Rineka Cipta

Notoadmodjo. 2012. Ilmu dan Seni Kesehatan Masyarakat. Jakarta: Rineka Cipta

Eslimah, 2009. Gambaran Pengetahuan dan Sikap Ibu Nifas Terhadap Status Gizi Selama Nifas di Zaal Kebidanan RSD Raden Mattaher Jambi tahun 2009 
Harnany, AS. 2006. Pengaruh Tabu Makanan, Tingkat Kecukupan Gizi, Konsumsi Tablet Besi dan Teh Terhadap Kadar Hemoglobin pada ibu Hamil di Kota Pekalongan Tahun 2006. Laporan Tesis Universitas Diponegoro, Semarang

Haryono, 2006. Persalinan di Daerah Terpencil. Dalam http://www.depkes.co.id.,diakses tanggal 8 Maret 2016.

Iskandar. 2006. Pantang makanan Setelah Kelahiran. (http://www.memokita.com, diakses pada tanggal 24 Maret 2016.

Iskandar. 2010. Mitos Keliru Seputar Makanan. Http://www.health.kompas.com diakses pada tanggal 23 Maret 2016

Ita Rahayu Aprilian. 2014. Tingkat Pengetahuan Ibu Nifas Tentang Pantang Makanan pada masa nifas di BPS Nunik Isdayati Gemolong Sragen Tahun 2014. Karya Tulis Ilmiah STIKes Kusuma Husada Surakarta

Kardinan. (2008). Pantang Makanan. (http://www.nikita.com.id, diakses pada tanggal 15 April 2016

Paath E, Rumdasih Y. dan Heryati. 2005. Gizi dalam Kesehatan Reproduksi. EGC: Jakarta

Romana, T. 2013. Mitos Keliru Seputar Makanan Ibu Nifas-Kompasiana Kesehatan. Health.kompas.com diakses tanggal 20 Januari 2016

Saleha, Siti. 2009. Asuhan Kebidanan Pada Masa Nifas. Jakarta: Salemba Medika

Sarwono. 2008. Psikologi Perkembangan. Jakarta : PT. Rineka Cipta.

Suherni. 2009. Perawatan Masa Nifas. Yogyakarta: Fitrimaya

Suprabowo, E. 2006. Praktik Budaya Dalam Kehamilan, Persalinan, Dan Nifas Pada Suku Dayak sanggau, Tahun 2006. Jurnal Kesehatan masyarakat Nasional Volume 1 FKM UI, Jakarta.

Swasono, M.F., 2004. Kehamilan, Kelahiran, Perawatan Ibu dan Bayi Dalam Konteks Budaya, Jakarta, UI Press

Winkjosastro. 2008. Ilmu Kebidanan. Jakarta: YBPSP 